\title{
With Al entering organizations, responsible leadership may slip!
}

\author{
David De Cremer ${ }^{1} \mathbb{B}$
}

Received: 26 August 2021 / Accepted: 30 August 2021 / Published online: 4 September 2021

(c) The Author(s), under exclusive licence to Springer Nature Switzerland AG 2021

\begin{abstract}
With the increasing influence of AI on the workings of organizations and the interests of its stakeholders, a consensus seems to have emerged that business leaders are more than ever attuned to being responsible in their adoption and use of intelligent technologies. In this opinion paper I develop the argument that this consensus is ill-founded. The emergence of AI ethics as a field and expertise has, first, created the idea among business leaders that their ethical duties can be carried out by machine. As a result, we see that business leaders are increasingly taking less responsibility in treating their workers in humane ways but rather as machines; a practice that ultimately leads to an approach, where workers' problems resulting from such a "machine first" work culture are seen to be remedied only by machine. I conclude with outlining several recommendations on how to install a "humans first" mindset and develop corresponding leadership styles (purpose-driven and inclusive) to consolidate a human-centred focus.
\end{abstract}

Not too long ago, I was invited to be part of a panel discussion on the use of AI technologies in society and organizations. At one point the moderator wanted to know from us panellists what we expected from the future of work now that business leaders are being responsible in using technology in their organizations. I waited to respond until it was my turn, but rather than responding to her question, I challenged her basic assumption, namely, that business leaders are acting and feeling responsible for the effect $\mathrm{AI}$ adoption has on their work force. In my view, rather the opposite is happening. I do not see many business leaders stepping up and wanting to take responsibility for how machine is disrupting our way of working in the context of organizations and society. In fact, I feel that with the introduction of AI in organizations, responsible leadership is slipping. Fed by the narrative of seeing "technology as primary" (and humans secondary) by technology leaders, many business leaders are on a path to emulate this kind of mindset. The result of this mindset is that business leaders feel less responsible for the decisions and actions they must take in a data-driven environment; simply because they have technology now to deal with this. Why am I saying this?

David De Cremer

bizddc@nus.edu.sg

1 Centre on AI Technology for Humankind (AiTH), NUS Business School, National University of Singapore, 15 Kent Ridge Drive, Singapore 119245, Singapore
Let me explain by taking AI ethics or responsible $\mathrm{AI}$ as an example. Inspired by tech companies' view on the ethical algorithm, the notion of responsible business is transforming more into an issue of technical competencies rather than human leadership abilities [1]. Google's ethics-as-a-service, for example, is setting the stage to elicit among business leaders the idea that ethics is something that can easily be fixed if you have the right technology at hand [2]. If so, business leaders may well feel less compelled to deal with ethics and moral business dilemmas in the future-isn't that's what we have machine for now? If the big technology companies can convince the business community that AI with a stamp of their approval that it's ethical is what they need, chances are that leaders will increasingly feel more comfortable to leave those difficult decisions to machine. In addition, with business leaders displaying less responsible behaviour, stakeholders are likely to be treated less in the right (human) way.

In fact, we already see this happening today. In their continuous search for growth, Facebook uses algorithms to ensure that as much information as possible is shared at their platform so more people will join their community [3]. For the company the practice of promoting equal access to information is referred to as fair use of algorithms, but at the same time, they do not wish to take responsibility for identifying misleading, polarizing, and immoral messages in this continuous stream of information that they feed to their members. Or take Amazon. The company has in the 
meantime gained a reputation of being a very demanding employer to satisfy their hunger for growth. Algorithms are being used to construct the new workplace, where employees are supervised (and fired) by machine and their time schedules adjusted in timely fashion based on continuous calculations of performance data [4]. Such environment has led to expectations that humans work in the same pace and with the same level of consistency as machine. Famous is the example of seeing bottles everywhere, because Amazon employees do not have the time anymore to take toilet breaks (machine doesn't use the toilet), so bottles will have to do [5]. Consequently, employees feel treated like robots and experience pressure and stress levels that are inhuman.

That such fearful expectations are widely shared emerged also in a survey that I ran among 239 full-time employed professionals (58.2\% female) using the online platform Prolific [6]. Results revealed that $59 \%$ of the surveyed professions agreed that the more their jobs will become automated the more they fear to be treated like a machine. At the same time, $76 \%$ respondents also expected that with automation increasing the pace of work will go up and $80 \%$ of them expected that with this increase of pace they will feel more stressful. Given Amazon's work context and my own survey results, it seems clear that the tendency is that leadership does not seem to feel responsible to think more deeply about how to create more humane work circumstances; rather they prefer looking at workers as data who are treated mathematically instead of with empathy.

For obvious reasons, this kind of use of algorithms in partnership with human stakeholders is creating circumstances that on the longer term will not lead to sustainable growth anymore-every human being has a breaking point when treated inhumane and unfairly. Acknowledging this fact, one would expect that leaders will be motivated to take up responsibility again and re-design the way machine is being used in their business. However, unfortunately, this does not seem to be happening either! What we see happening is that machine is offered as a solution to the problems it has caused [7]. For example, in call centres, where humans experience the pressure to act as scripted machines-and denying their human urges to genuinely help others-employees display more quickly frustrations, anger and less empathy to customers. Rather than business leaders changing the work circumstances and finding better ways of motivating their employees, this typical leader responsibility is outsourced to companies that develop machines to teach humans more empathy. Indeed, companies like Cogito use AI to coach call centre workers to deliver service in empathic ways.

So, the development that I see happening is that transferring power to machine with the goal to promote growth and efficiency in the work context turns employees into halfbaked machines who are stripped from their human habits only to find out that these human abilities at the end of the day do have value. However, instead of bringing then again, more humanity to the work floor-by means of responsible leaders who treat their employees in better ways-the dominant idea of "technology first" leads business leaders to find again the solution with machine. What can this development teach us when it comes down to genuinely leading AI adoption in responsible ways?

First, avoid fostering a mindset, where machine is seen as first, with the ultimate consequence that humans are identified as secondary. Today, the focus is so much on innovating technology itself [8], that many of us are expecting AI to deliver services that will surpass human intelligence levels soon, but unfortunately this may come at a cost. Indeed, we may lose our human superpowers of empathy, creativity, and imagination to envision-all skills that leaders and responsible companies need. The risk of losing what defines us as humans should make us realize again that AI advancement is - and always has - meant to be human-centred. In other words, the power of technology needs to be elevated to serve human interests and not put those of machine first.

Second, rather than thinking that human leadership will be less needed, because AI will be capable to make decisions, we need to realize that we will need more, and better leadership training focused on people's needs and uncertainties than before [9]. AI is not here to take over leadership responsibilities. It is a tool that can help leaders make better decisions. Therefore, business leaders need to be aware that in the AI era the only change that will happen to their role is that they are expected to raise their game. They will need to excel even more in their soft skills by paying more attention to how they treat their work force. In fact, leadership will need a human touch to use the advice delivered by AI in ways that help them envision better strategies that will further promote the interests of all their stakeholders. With the introduction of $\mathrm{AI}$ in organizations, leaders will be expected to take more responsibilities instead of less.

Third, by acknowledging that leadership in the future requires a human touch more than ever to elevate the power of technology, two leadership types will be necessary. In my recent book "Leadership by Algorithm: Who leads and who follows in the AI era", I identify those two types as purposedriven and inclusive leadership [1]. The lesson that relying too much —or bestowing responsibility—on AI may lead to a less humane work context makes clear that the purpose of any leader and company will have to be defined by human values and not by machine logic, where data will define our purpose. Leaders will need to ensure that the values their company endorses is salient at all levels within the organization, so they can ask the right questions and the right kind of data will be used to try solving those questions. To achieve such purpose-driven way of doing business also implies that leaders promote an inclusive work context, where those 
working with the data and algorithms interact and communicate with those who are experts in business processes. Only this way can a digitally inquisitive mindset create business value that is seen as fair and responsible towards the interests of all stakeholders.

\section{Declarations}

Conflict of interest On behalf of all authors, the corresponding author states that there is no conflict of interest.

\section{References}

1. De Cremer, D.: Leadership by algorithm. Who leads and who follows in the AI era? Harriman House Publishing, London (2020)

2. De Cremer, D., Kasparov, G.: The ethical AI-paradox: Why better technology needs more and not less human responsibility. AI and Ethics (in press)

3. Hao, K.: How Facebook got addicted to spreading misinformation. MIT Technology Review. March 11. Retrieved from: https:// www.technologyreview.com/2021/03/11/1020600/facebook-respo nsible-ai-misinformation/ (2021). Accessed 25 Aug 2021

4. Soper, S.: Fired by Bot at Amazon: It's you against the machine. Bloomberg. June 28. Retrieved from: https://www.bloomberg. com/news/features/2021-06-28/fired-by-bot-amazon-turns-tomachine-managers-and-workers-are-losing-out (2021). Accessed 25 Aug 2021

5. Liao, S.: Amazon warehouse workers skip bathroom breaks to keep their jobs, says report. The Verge. April 16. Retrieved from: https://www.theverge.com/2018/4/16/17243026/amazon-wareh ouse-jobs-worker-conditions-bathroom-breaks (2021). Accessed 25 Aug 2021

6. De Cremer, D. (2021). Do executives see companies turn into machines? Unpublished data

7. O'Connor, S.: It's creepy that AI is teaching workers to be more human. The Financial Times. April 13. Retrieved from: https:// www.ft.com/content/758e0a2f-3507-4b66-990a-73310d8f588b (2021). Accessed 25 Aug 2021

8. De Cremer, D.: Why Mark Zuckerberg's Leadership Failure was a Predictable Surprise. The European Business Review, May-June, 7-10 (2018)

9. De Cremer, D.: Artificial Intelligence will change how we think about leadership - An interview with David De Cremer. Knowledge@Wharton. November 2. Retrieved from: https://knowledge. wharton.upenn.edu/article/artificial-intelligence-will-changethink-leadership/ (2020b). Accessed 25 Aug 2021

Publisher's Note Springer Nature remains neutral with regard to jurisdictional claims in published maps and institutional affiliations. 